\title{
THE EFFECT OF STUDENTS' LEANING STYLE AND SELF-CONCEPT TOWARD MATHEMATICAL CREATIVE THINKING ABILITY IN LINEAR ALGEBRA SUBJECT
}

\author{
Dian Purwaningsih \\ Mathematics Department Peradaban University \\ dian.purwaningsih24@yahoo.com
}

\begin{abstract}
The students' low ability in absorbing the information they got in the learning activity. Another factor was students' self-concept which not quite good. Students' self-concept can be declared through their selfunderstanding, as well as their self-confidence toward their ability to solve their assignment or problem. This study was aimed to investigate the effect of learning style toward the mathematical creative thinking ability, to investigate the effect of self-concept toward mathematical creative thinking ability, and to investigate the effect of learning style and self-concept toward mathematical creative thinking ability. This study was one of the ex-post facto with descriptive approach. Based on the aim of this study, this study used regression analysis technique in the form of simple analysis regression and double analysis regression. The result of this study showed that there was an effect of learning style toward mathematical creative thinking ability, there was an effect of self-concept toward mathematical creative thinking ability, and there was an effect of learning style and self-concept toward mathematical creative thinking ability.

Keyword: learning style, self-concept, mathematical creative thinking ability
\end{abstract}

\section{INTRODUCTION}

Mathematics has an important role in everyday life. It can be used or applied in every activity in real life, whether science or technology. Due to the importance of mathematics, efforts are needed to master the mathematics subject. Therefore, you need to learn mathematics, whether in elementary school, junior/senior high school or even in the university.

Based on Constitution of the Republic of Indonesia No.12 year 12 about higher education, it states that to improve nation's competitiveness in facing globalization in the entire fields, the study in higher education is needed due to improving the science knowledge and technology. It also used to produce intellectual, scientist, and/or cultured professional and creative, tolerant, democratize, tough character, and brave enough to defend the truth for notion benefits. 
One of the scientific knowledge that can produce intellectual and creative students is mathematics. In the educational field, mathematics learning aims to produce students who can think, comprehend, and solve the problems. The purpose of mathematics learning will be achieved if it is seen from the good learning outcome. One of modality achievement of good learning outcome is based on students' learning style. Learning style is a combination of how someone absorbs, sets and process the information. De Potter, dkk (2007) suggest that there are three learning styles which are 1) visual learning style, 2) auditory learning style, and 3) kinesthetic learning style. As can be seen from the importance of learning style, it becomes of the aspects that should have more attention.

Based on the result of the observation of the first semester students of mathematics education of Peradaban University, it is showed that students have low ability in absorbing the information in the learning process. Another factor was students' deficient selfconcept. The students' self-concept defined based on students' self-understanding and confidence toward their ability in solving the tasks or problems. The students' deficient learning style and self-concept obviously affected their thinking ability. Bishop (Pehnoken, 1997) states that people need two mathematical thinking skills, which are creative thinking and analytic thinking (logical thinking).

The aim of this study was: (1) to investigate the effects of learning style toward mathematical creative thinking ability, (2) to investigate the effects of self-concept toward mathematical creative thinking ability, (3) to investigate the effects of learning and selfconcept toward mathematical creative thinking ability.

\section{RESEARCH METHODOLOGY}

In this study, the researcher used ex-post facto research design with descriptive approach. Moreover, regression analysis technique in the form of simple regression analysis and multiple regression analysis were used by the researcher to reach the aim of this study. The subject of this study was the first semester students of mathematics education of Peradaban University, in the academic year of 2016-2017. The independent variable of this study was the students' learning style and self-concept, while the dependent variable was the students' mathematical creative thinking ability. 


\section{DISCUSSION}

In this study, the researcher conducted regression test to investigate the effect of learning style $\left(x_{1}\right)$ and self-concept $\left(x_{2}\right)$ toward mathematical creative thinking ability $(y)$ at once by using simple regression statistic test and multiple regression tests using SPSS.

\section{To investigate the effect of learning style toward mathematical creative thinking} ability by the hypothesis as follows.

a. To analyze the effect of learning style towards mathematical creative thinking ability the researcher used simple regression test, see Table 1.

Table 1. ANOVA ${ }^{\text {b }}$

\begin{tabular}{|c|c|c|c|c|c|c|}
\hline \multicolumn{2}{|c|}{ Model } & Sum of Squares & $d f$ & Mean Square & $\mathrm{F}$ & Sig. \\
\hline \multirow[t]{3}{*}{1} & Regression & 449.643 & 1 & 449.643 & 33.826 & $.000^{\mathrm{a}}$ \\
\hline & Residual & 265.857 & 20 & 13.293 & & \\
\hline & Total & 715.500 & 21 & & & \\
\hline
\end{tabular}

a. Predictors: (Constant), Learning_style

b. Dependent Variable: Creative_thinking

Based on Table 1 above, it showed that $\mathrm{F}=33,826$ with sig $0,000<0,05$ which meant $\mathrm{H}_{0}$ was rejected. The result indicated that the equation of the regression test on learning style affected mathematical creative thinking ability.

b. To measure the value of learning style effect toward mathematical creative thinking ability, see Table 2.

Table 2. Summary Model

\begin{tabular}{|l|r|r|r|r|}
\hline Model & $\mathrm{R}$ & R Square & \multicolumn{1}{|c|}{$\begin{array}{c}\text { Adjusted R } \\
\text { Square }\end{array}$} & Std. Error of the Estimate \\
\hline 1 & $.793^{\mathrm{a}}$ & .628 & .610 & 3.646 \\
\hline
\end{tabular}

a. Predictors: (Constant), Learning_style

The value of learning style effect can be seen from $R$ Square value $=0,628=62,8 \%$ that meant $62,8 \%$ mathematical creative thinking ability was affected by learning style, while the rest $37,2 \%$ was affected by other factors.

c. To investigate the equation of regression, see Table 3.

Table 3. Coefficients ${ }^{\mathrm{a}}$

\begin{tabular}{|c|c|c|c|c|c|c|}
\hline \multirow{2}{*}{\multicolumn{2}{|c|}{ Model }} & \multicolumn{2}{|c|}{$\begin{array}{l}\text { Unstandardized } \\
\text { Coefficients }\end{array}$} & \multirow{2}{*}{\begin{tabular}{|c|}
$\begin{array}{c}\text { Standardized } \\
\text { Coefficients }\end{array}$ \\
Beta \\
\end{tabular}} & \multirow[b]{2}{*}{$\mathrm{t}$} & \multirow[b]{2}{*}{ Sig. } \\
\hline & & B & Std. Error & & & \\
\hline \multirow[t]{2}{*}{1} & (Constant) & 44.169 & 6.807 & & 6.489 & .000 \\
\hline & Learning_style & .486 & .084 & .793 & 5.816 & .000 \\
\hline
\end{tabular}

a. Dependent Variable: creative_thinking 
Table 3 showed the correlation between learning style toward mathematical creative thinking ability on the regression equation. The equation regression showed $\hat{Y}=44,169+0,486 x_{1}$ that meant in every one unit of an additional learning style variable increased 0,486 value of mathematical creative thinking ability. The result above indicated $\mathrm{H}_{0}$ was rejected and $\mathrm{H}_{1}$ was accepted. It meant that learning style affected mathematical creative thinking ability.

2. To investigate the effect of self-concept toward mathematical creative thinking ability, see the following hypothesis.

a. To analyze the effect of self-concept toward mathematical creative thinking ability, the researcher used regression test, see Table 4.

Table 4. ANOVA ${ }^{\mathrm{b}}$

\begin{tabular}{|l|r|r|r|r|r|}
\hline Model & Sum of Squares & df & Mean Square & F & Sig. \\
\hline $1 \quad$ Regression & 497.909 & 1 & 497.909 & 45.766 & $.000^{\mathrm{a}}$ \\
Residual & 217.591 & 20 & 10.880 & & \\
Total & 715.500 & 21 & & & \\
\hline
\end{tabular}

a. Predictors: (Constant), self_concept

b. Dependent Variable: Creative_thinking

Based on the data above, it showed that $F$ value $=45,766$ with sig $0,000<0,05$ that meant $\mathrm{H}_{0}$ was rejected. It meant that the regression equation of self-concept affected mathematical creative thinking ability.

b. To measure the value of self-concept effect toward mathematical creative thinking ability, see Table 5 .

Table 5. Summary Model

\begin{tabular}{|l|l|l|l|l|}
\hline Model & R & R Square & Adjusted R Square & Std. Error of the Estimate \\
\hline 1 & $.834^{\mathrm{a}}$ & .696 & .681 & 3.298 \\
\hline
\end{tabular}

a. Predictors: (Constant), Self_Concept

The value of self-concept can be seen from $\mathrm{R}$ Square value $=0.696=69.6 \%$ which meant that $69.6 \%$ of the mathematical creative thinking ability was affected by selfconcept while the $34.3 \%$ was affected by other factors. 
c. To investigate the form of the regression equation, see Table 6 .

Table 6. Coefficients ${ }^{\mathrm{a}}$

\begin{tabular}{|ll|l|l|l|l|l|}
\hline \multirow{2}{*}{ Model } & \multicolumn{3}{|l|}{ Unstandardized Coefficients } & $\begin{array}{l}\text { Standardized } \\
\text { Coefficients }\end{array}$ & \\
\cline { 2 - 5 } & $\mathrm{B}$ & Std. Error & Beta & $\mathrm{t}$ & Sig. \\
\hline 1 & (Constant) & 26.873 & 8.400 & & 3.199 & .005 \\
& Konsep_diri & .679 & .100 & .834 & 6.765 & .000 \\
\hline
\end{tabular}

a. Dependent Variable: Thinking_creative

From the Table 6 above, it can be seen that the correlation between self-concept toward mathematical creative thinking skill which is showed by the regression equation. The regression equation was $\hat{Y}=26,873+0,679 x_{2}$ It meant that the addition of self-concept variable as one number, so it will add the score of mathematical creative thinking to 0.679 points. Based on this result, $\mathrm{H}_{0}$ was rejected and $\mathrm{H}_{1}$ was accepted. It meant that the self-concept affected the mathematical creative thinking.

\section{To investigate the effect of learning model and self-concept toward mathematical} creative thinking using this hypothesis below.

a. To analyze the effect of learning model and self-concept toward mathematical creative thinking, double regression is used and it obtained the result, see Table 7.

Table 7. ANOVA ${ }^{b}$

\begin{tabular}{|ll|l|l|l|l|l|}
\hline Model & Sum of Squares & df & Mean Square & F & Sig. \\
\hline $1 \quad$ Regression & 546.076 & 2 & 273.038 & 30.620 & $.000^{\mathrm{a}}$ \\
\multicolumn{1}{|c|}{ Residual } & 169.424 & 19 & 8.917 & & \\
\multicolumn{2}{c|}{ Total } & 715.500 & 21 & & & \\
\hline
\end{tabular}

a. Predictors: (Constant), Self_concept_Learning_model

Table 7. ANOVA ${ }^{b}$

\begin{tabular}{|ll|l|l|l|l|l|}
\hline Model & Sum of Squares & df & Mean Square & F & Sig. \\
\hline 1 & Regression & 546.076 & 2 & 273.038 & 30.620 & $.000^{\mathrm{a}}$ \\
\multicolumn{1}{|c|}{ Residual } & 169.424 & 19 & 8.917 & & \\
\multicolumn{2}{|c|}{ Total } & 715.500 & 21 & & & \\
\hline
\end{tabular}

b. Dependent Variable: Thinking_creative 
Based on the result above, it showed that the value of $F=30,620$ with sig $0,000<0,05$ which meant $\mathrm{H} 0$ was rejected. It meant that double regression equation of learning style and self-concept affected the mathematical creative ability, see Table 8.

Table 8. Model Summary

\begin{tabular}{|l|c|r|r|r|}
\hline Model & $\mathrm{R}$ & $\mathrm{R}$ Square & $\begin{array}{c}\text { Adjusted R } \\
\text { Square }\end{array}$ & $\begin{array}{c}\text { Std. Error of the } \\
\text { Estimate }\end{array}$ \\
\hline 1 & $.874^{\mathrm{a}}$ & .763 & .738 & 2.986 \\
\hline
\end{tabular}

a. Predictors: (Constant), self_concept, learning_style

The value of self-concept and learning style effects can be seen from $\mathrm{R}$ Square value = $0,763=76,3 \%$ which meant $76,3 \%$ of mathematical creative ability was affected by learning style and self-concept, while the rest $23,7 \%$ was affected by other factors.

b. To investigate the form of regression equation, see Table 9

Table 9. Coefficients ${ }^{\mathrm{a}}$

\begin{tabular}{|c|c|c|c|c|c|c|}
\hline \multirow{2}{*}{\multicolumn{2}{|c|}{ Model }} & \multicolumn{2}{|c|}{$\begin{array}{l}\text { Unstandardized } \\
\text { Coefficients }\end{array}$} & \multirow{2}{*}{$\begin{array}{c}\begin{array}{c}\text { Standardized } \\
\text { Coefficients }\end{array} \\
\text { Beta }\end{array}$} & \multirow[b]{2}{*}{$\mathrm{t}$} & \multirow[b]{2}{*}{ Sig. } \\
\hline & & B & Std. Error & & & \\
\hline \multirow[t]{3}{*}{1} & (Constant) & 27.156 & 7.606 & & 3.570 & .002 \\
\hline & Learning_style & .237 & .102 & .387 & 2.324 & .031 \\
\hline & Self_concept & .446 & .136 & .547 & 3.289 & .004 \\
\hline
\end{tabular}

a. Dependent Variable:creative_thinking

The correlation between learning style and self-concept toward the mathematical creative thinking ability that shown in the regression equation. The equation regression was $\hat{Y}=27,156+0,237 x_{1}+0,446 x_{2}$, which meant, every one unit of an additional learning style variable increased 0,237 and every one unit of an additional mathematical creative thinking ability was 0,446 . Based on those results, it indicated that $\mathrm{H} 0$ rejected and $\mathrm{H} 1$ accepted. It meant that self-concept of learning style affected the mathematical creative thinking ability.

\section{CONCLUSION:}

1. There was an effect of learning style toward the mathematical creative thinking ability.

2. There was an effect of self-concept toward the mathematical creative thinking ability.

3. There was an effect of learning style and self-concept toward the mathematical creative thinking ability. 


\section{REFERENCES}

Ballone, L. M. dan Czerniak, C. M. 2001. Teacher's beliefs abut accommodating students' learning styles in science classes [Electronic version]. Electronic Journal of Science Education, 6(2), 1-41.

De Potter, B, dan Hernacki, M. 2007. Quantum Learning : Familiarize Study Convenient and Fun.. Bandung : Kaifa.

Djaali. 2007. Educational Psychology. Jakarta: Bumi Aksara.

Kiswandono, I. 2000. Creative Thinking An Approach Towards an Architectural Thinking. Petra Christian University.

Munandar, U. 1999. Developing Talent and Creativity of School Children. Jakarta: Gransindo.

Nasution. 2008. Various Approaches in Learning and Teaching Processes. Jakarta: Bumi Aksara.

Pehkonen, E. 1997. The State-of-Art in Mathematical Creativity, ZDM International Reviews on Mathematical Education. from: https://www.emis.de/journals/ZDM/ zdm973a1.pdf

Risbang Ristekdikti. 2012. Law of the Republic of Indonesia Number 12 Year 2012 on Higher Education.

Siswono, E. 2005. "Efforts to Improve the Creative Thinking Skills of Students through Problem Filing ". Journal of Mathematics and Science Education. Year X, No. 1, June 2005. ISSN 1410-1866, pp. 1-9.

Slameto. 2010. Learning and Its Affecting Factors. Jakarta: Rineka Cipta.

Sudjana. 2005. Statistic Methods. Bandung : Tarsito

Sugiyono. 2011. Quantitatif, Qualitatif and $R \&$ D Research Method. Bandung: Alfabeta.

Sukestiyarno. 2010. SPSS Assisted Research Data Assessment. State University of Semarang.

Supardan, D. 2008. Introduction to Social Studies a Structural Approach. Jakarta : Bumi Aksara

Syam, Nina W. 2012. Social Psychology as the Roots of Communication Science. Bandung : Simbiosa Rekatama Media.

Tabrizi, at al. 2011. "Relationship between Creative Thinking And Anxiety Among Adolescent Boys And Girls in Tehran, Iran". International journal of Humanistic and Social Science. Vol 1 no 19

Uno, H.B. 2006. Orientation in Learning Psychology. Jakarta: Bumi Aksara. 